\title{
IXODES TICKS - TRANSMITTERS OF DANGEROUS TRANSMISSIBLE INFECTIONS AND INVASIONS AGENTS
}

\author{
N. M. SOROKA, Doctor of Veterinary Sciences, Professor \\ https://orcid.org/0000-0003-4659-6666 \\ E-mail:5278823@ukr.net
}

National University of Life and Environmental Sciences of Ukraine, Kyiv, Ukraine

V. V. NEDOSEKOV, Doctor of Veterinary Sciences, Professor https://orcid.org/0000-0001-7581-7478

E-mail: nedosekov06@gmail.com

National University of Life and Environmental Sciences of Ukraine, Kyiv, Ukraine

N. P. OVCHARUK, Candidate of Veterinary Sciences

https://orcid.org/0000-0001-8686-1220

E-mail:v210116@meta.ua

Separate subdivision of the National University of Life and Environmental Sciences of Ukraine "Nemishayev Agrotechnical College", Nemishayeve, Ukraine

V. M. OVCHARUK, Candidate of Veterinary Sciences

https://orcid.org/0000-0003-1230-4506

E-mail:v210116@meta.ua

Separate subdivision of the National University of Life and Environmental Sciences of Ukraine "Nemishayev Agrotechnical College", Nemishayeve, Ukraine

O. O. KRAVCHUK, Veterinarian

https://orcid.org/0000-0002-5151-2239

E-mail: 1999kravchuk@gmail.com

National University of Life and Environmental Sciences of Ukraine, Kyiv, Ukraine

\begin{abstract}
The article considers domestic and foreign experience in the spread of Ixodes ticks - vectors of dangerous transmissible infections and invasions in the park areas of Ukraine and preventive measures against Ixodidosis of animals and humans. The material for the study was the data of veterinary reporting obtained from the state regional laboratories of the State Service of Ukraine on Food Safety and Consumer Protection for 2018-2019. The research was conducted at the Department of Parasitology and Tropical Veterinary Medicine of the National University of Life and Environmental Sciences of Ukraine. Ixodes ticks, previously collected in the park zone of Kyiv, were used for research. We analyzed the results of studying the Ixodes ticks for the presence of pathogens of dangerous transmissible infections and invasions, as well as the treatment of dogs with Ixodidoses.

We consider it important to timely prevent animals from ticks, the studying of ticks in the areas of their possible spread; analysis of the ecological situation within three to four years in the area where ticks are most common; creation of maps using the Geographic
\end{abstract}


information systems that reflect the dynamics of diseases transmitted by Ixodes ticks; informing the population to prevent the spread of infected ticks.

Prospects for further research are the search for effective acaricidal drugs, taking into account their toxicity.

Keywords: Ixodes ticks, spread, risks, transmissible diseases, Ixodidoses of animals

\section{Introduction}

Ixodes ticks (in Latin Ixodidae) are carriers of dangerous transmissible infections and invasions, such as Tickborne encephalitis (TBE), Tick-borne borreliosis or Lyme borreliosis, Tularaemia (in Latin Tularenia), Tick-borne rickettsial pathogens, in particular, query fever (Q-fever) and Marseilles fever (Galat, 2003; Nikiforova, 2007; Luginin, 2011). Tick-borne encephalitis and Lyme borreliosis (Lyme disease), from which both humans and animals suffer, are the most well-known and widespread in Ukraine (Klymniuk, 2017).

The transmission of dangerous pathogens occurs after the Ixodes tick bite. However, even a short tick stay on an animal's body can result in its infection. This feature is associated with factors of immunosuppression of the secretion of glands that enter the Ixodes ticks during the bite (Afzelius, 1910; Appel et al., 1993). Therefore, we believe, that Ixodes are a vector of transmission of dangerous transmissible diseases of humans and animals (Burgdorfer, 1984).

The widespread ticks distribution of the genus Ixodidae in the world, including Ukraine, the mosaic nature of their spatial distribution, the adaptive diversity of life cycles, as well as the potential danger as vectors of infectious and invasive diseases of animals and humans make the task of their detailed studying relevant. Thus, it is important to study the dynamics of the number of Ixodes in different countries and regions of Ukraine, as well as the structure of the fauna, features of biotope distribution, the development cycle of these ticks, and others. The research on the territory of Ukraine, where the natural center of dangerous transmissible infections and invasions have been registered, is important.

\section{Analysis of recent researches and publications}

The studies of Ukrainian scientists V. F. Galat, A. V. Berezovsky, M. P. Prus are devoted to Lxodidae. N. M. Soroka (2003) considered and examined invasive animal diseases (Galat at al., 2003); O. V. Nikiforova (2007) analyzed the spread of Ixodes ticks as carriers of pathogens of Borrelia burgdorferi sensu lato, Babesia microti, Ehrlichia phagocytophila geno group, Bartonella spp., Rickettsia spot fever group, Toxoplasma gondii in the south-eastern part of Ukraine (Nikiforova, 2007); M. S. Luginin (2011) investigated trophy-consortial relationships of Ixodes ticks in forest ecosystems and their role in the spread of pathogens of natural focal diseases in humans and animals (Luginin, 2011); O. E. Galatiuk, O. O. Peredera, I. V. Lavrinenko, I. A. Gernosik (2018) analyzed infectious diseases of dogs (Galatiuk et al., 2018).

Dangerous pathogens of transmissible diseases transmitted by Ixodes ticks, is researched and studied in European countries (Steere et al., 1977; Lindgren et al., 2006; Littman et al., 2018; Regional Committee for Europe EUR/ 
RC68/16 68th session Rome, 2018). So the pathogen Borrelia burgdorferi was registered in Germany by Zeman (1997) and Hönig et al. (2011), in Italy - by Rizzoli et al. (2004). Also, Schwarz et al. (2009) made predictions about the spread of Ixodes in Germany, and Braga (2012) - in Scotland.

In Ukraine, the pathogen Toxoplasma gondii in Ixodes ticks of the genus Ixodes was detected and studied by M. V. Galat et al. (Galat et al., 2016).

The prevalence of infection and $I x$ odes scapularis Say, its activity season, survival, wintering and development (Acari: Ixodidae) were studied by Zachary C. Polk (Manitoba, Canada, 2017); Meryl P. Littman, Bernhard Gerber, Richard E. Goldstein, Mary A. Labato, Michael R. Lappin, George E. Moore (American College of Veterinary Internal Medicine, ACVIM, 2018).

Researchers analyzed the reasons for the geographical distribution of infected and infested Ixodes; developed diagnostic tests to rule out coinfection and other causes of clinical signs that could potentially be associated with Lyme disease; tested in the experiment effective methods for treatment of dogs and other animals for arthritis and nephritis caused by Ixodes, as well as developed treatment regimens for Ixodes (Littman et al., 2018; Regional Committee for Europe EUR/ RC68/16 68th session Rome, 2018).

Purpose. The aim of the study is to analyze the prevalence of Ixodes as vectors of dangerous transmissible infections and invasions in Ukraine and to identify risks for their prevention.

\section{Materials and methods of research}

For the study, we collected Ixodes in the forest park areas of Kyiv and the Kyiv region. We used the conventional method of direct selection of Ixodes in animals. It is based on a selective or complete collection of Ixodes mites found on dogs of different breeds. We used a thin wooden board (size 15-20 $\times 5 \mathrm{~cm}$ ) with pointed long edges for select Ixodes from dogs with short and straight hair. We combed the board against the wool and looked behind the plate for lightened skin under the conditions of Ixodes.

In addition, we also searched Ixodes ticks conventional method, namely, collecting them from the environment in a simple white cloth material (size $60 \times 100 \mathrm{~cm}$ ). Adults of Ixodes (females, males) were collected from vegetation; preimaginal stages (larvae, nymphs) for combing small dogs. In total, we examined 150 adults, 60 nymphs, and 30 larvae of Ixodes, including adult genera Ixodes 110 and Dermacentor - 40.

The polymerase chain reaction was used to isolate the DNA of Borrelia burgdorferi and Toxoplasma gondii from Ixodes ticks. The results of the reaction were analyzed using special software.

Ixodes ticks were mechanically ground, incubated at $56^{\circ} \mathrm{C}$ with the addition of proteinase $\mathrm{K}$ for 16 hours. Proteinase $\mathrm{K}$ is a non-specific serine protease with high proteolytic activity. The obtained suspension was centrifuged, the supernatant was collected and DNA isolation of pathogens was performed using a special set (according to the instructions for use). This set contained a mixture of required primers that are necessary for DNA replication during amplification.

\section{Results of the research and their discussion}

We conducted experimental studies during 2018-2019 in periods of high activity of Ixodes ticks - in spring (April, May), and in early summer (June), and 
autumn (September, October). According to the results of the research, Ixodes ticks of the genera Ixodes and Dermacentor were found in the forest park zones of Kyiv and Kyiv region. Other genera of Ixodes ticks were not registered.

Laboratory tests revealed the presence of DNA of Borrelia burgdorferi and Toxoplasma gondii in the body of Ixodes, larvae and nymphs of the genus Ixodes. We did not detect these pathogens in ticks, larvae, and nymphs of the genus Dermacentor.

The presence of Borrelia burgdorferi in Ixodes of the genus Ixodes confirms the main natural source of infection with this pathogen in various species of animals and humans in Ukraine and, in particular, in the city of Kyiv and the Kyiv region. At that time, the detection of Toxoplasma gondii in Ixodes ticks indicates one of the possible sources of infection with the pathogen in animals and humans.

The results of the research indicate that a stable natural center of Lyme borreliosis and toxoplasmosis has formed in the forest-park zones of Kyiv and Kyiv region.

It should be noted that the forest park zones of Kyiv and the Kyiv region have sufficient soil moisture, the almost optimal ambient temperature in recent years, diverse flora and fauna, which contributes to the mass spread of Ixodes ticks and creates favorable conditions for the circulation of pathogens Borreliandurg in them.

Investigating the emergence of mites of the genus Ixodes and Dermacentor from the winter diapause, in recent years there have been earlier periods, and the period of activity lasts until mid-November, which leads to an increase in numbers and, consequently, attacks on animals and humans.
In this regard, the epizootic and epidemic situation of Lyme borreliosis disease and toxoplasmosis in Kiev and the Kiev region in recent years is regarded as unstable. In particular, the level of infection of humans and dogs with the pathogen Borrelia burgdorferi remains quite high.

Our results coincide with the data of state laboratories of veterinary medicine, which indicate the detection of Ixodes ticks of the genus Ixodes pathogens of Lyme borreliosis. In addition, peaks of Ixodes ticks attacks on domestic and farm animals causing ixodidosis are recorded.

Currently, the annual dynamics of infection of animals and humans with Borrelia burgdorferi and Toxoplasma gondii is characterized by a pronounced seasonality associated with the period of activity of ticks of the genus Ixodes. It is established that the largest number of attacks of Ixodes ticks on dogs and humans is registered in May-June and September-October.

Ixodes ticks bite involving a violation of the integrity of the skin, allergic reactions to foods salivary glands, irritation, and inflammation.

With a significant invasion, ticks cause ixodidosis, which is characterized by the development of anemia and severe stress and is accompanied by loss of appetite and exhaustion, decreased resistance of animals.

It should be noted, that, currently, there are new enzootic areas in the Kyiv region, both at the site of infection of humans and animals (suction of ticks), and the results of studies of Ixodes ticks (positive findings). At the same time, natural foci of Lyme borreliosis were found in most forest park areas of the city and region. Therefore, the risk of infecting humans and animals depends on the number of infected and infested 
Ixodes ticks in the region and the frequency of contact with them.

First of all, we focused on the features of the biology and ecology of $I x$ odes ticks to determine the risks associated with the spread of Ixodes mites and their prevention.

As it is known (Nikiforova, 2007; Luginin, 2011), the development cycle of Ixodes ticks covers three active stages: larva, nymph, and imago (female, male). At each stage of their transformation and to maintain their vital activity, Ixodes mites find a suitable host to feed on its blood and maintain the temperature they need (Fig. 1).

As a rule, an adult tick needs a large host, a mammal, such as a deer. Larvae and nymph need a small host, such as a rodent, a small bird, and a dog. After feeding, female Ixodes ticks hide in vegetation and the upper layers of the soil and lay thousands of eggs, and then die. At the same time, larvae and nymphs go through stages of development to adult directly on animals or also in the environment.
The efficiency of transmission of Borrelia in the body of ticks in different individuals ranges from 26.5 to $81.4 \%$. The spirochetes appear in the hemolymph of the mite in the first hours after infectious blood suction on the donor animal, and after 4-6 days in the body of the female mite. They were found not only in the intestine, but also in the brain, Malpighian tubes, and, most importantly, in the salivary glands and eggs.

The nymph bites, in contrast to adults, in the vast majority of cases go unnoticed, which should be taken into account when collecting epidemiology. The same role in the circulation and preservation of the causative agent of Lyme borreliosis belongs to small mammals in which the pathogen experiences an inter-epizootic period. The rodents can be carriers of Borrelia for almost their entire lives and play a significant role as a reservoir of infection in nature.

It is noted that some Ixodes ticks develop from eggs, two immature stages

Adult (Lat. Imago) mite lays eggs

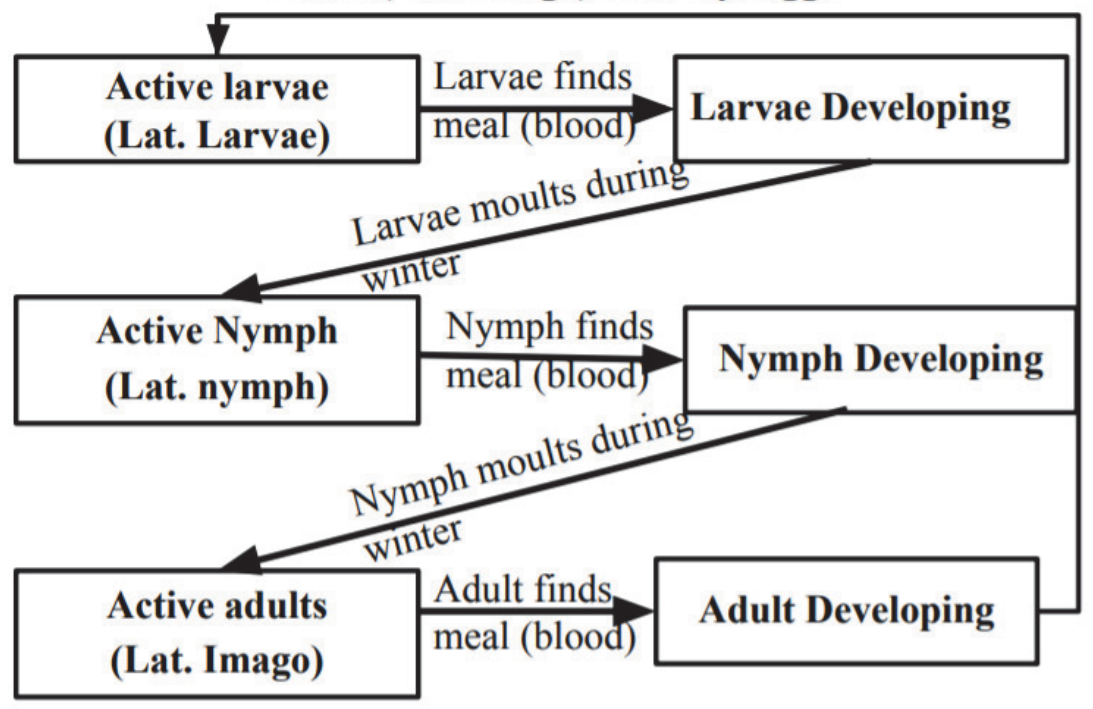

Fig. 1. The life cycle of Ixodes ticks 
(larvae and nymphs), to adults, within 1-3 years. Each immature stage in the development of Ixodes mites requires feeding on the blood of certain animals, which takes several days. In addition, the environment has a very sensitive effect on their activity and survival. Gilbert et al. (2014) investigated that ticks of the genus Ixodes, more than other genera, are sensitive to low temperatures. Therefore, they usually retain their viability by hiding in vegetation, soil (their behavior, known as a quest). In conclusion, scientists found that "questing behavior in response to temperature varies between I. Ricinus populations in relation to thermal climate with a higher proportion of the population questing at lower temperatures if they are from cooler climates" (Gilbert et al., 2014).

Randolph et al. (2002) found that these ticks try to avoid drying out, especially at low or high humidity. This conclusion was validated when emergence dates of unfed ticks predicted from a day-degree summation development model coincided precisely with the first appearance in the field of ticks with high fat content (Randolph et al., 2002). It is important to consider these factors to predict the future activity of Ixodes ticks or their numbers.

The Geographic Information Systems (GIS) are now increasingly used to make spatially large-scale associations between environmental factors and disease risk parameters. These maps have enabled us to gain insight about diseases ranging, for example, from Encephalitis to Lyme borreliosis, or to focus on the fact that GIS to simulate the dynamics of diseases transmitted by Ixodes ticks. The Medical GIS will remain a lasting approach for understanding populations and the world we live in.
The presentation of data in the form of an interactive portal of online maps is an ideal way to convey information to the public. For example, map of "Ticks and tick-borne diseases in South Bohemia and regions of Bavaria 2008-2020" by scientists of University of South Bohemia, VŠB - Technical University Ostrava, Institute of Parasitology, BC AS CR, v.v.i. (http://gisak.vsb.cz/klistata/index_en.html). The main purpose of the map portal is to make the data on the occurrence of ticks and tick-borne pathogens in South Bohemia, Lower Bavaria, and Upper Palatinate available to the public (Švec et al., 2009; Honig et al., 2015; Švec et al., 2019; Honig et al., 2019; Zubriková et al., 2020).

To prevent ixodidosis in animals, a variety of chemical drugs (acaricides, insecticides) of domestic and foreign manufacturers and repellents are applied to the skin in the form of aerosols, suspensions, powder, drops, shampoo, as well as collars, tapes. However, some of them are not effective enough, and some are even toxic.

Thus, analyzing the epizootological and epidemiological situation, we should talk about the spread of Lyme borreliosis and toxoplasmosis among humans and animals and the expansion of their vectors, in particular the increase in the number of ticks of the genus Ixodes in forest parks of Kyiv and Kyiv region. The main reason for this phenomenon, in our opinion, is climate change and ecology. In addition, there is a set of natural and social factors that create receptive conditions for the reproduction of Ixodes ticks. In particular, the mitigation of the climate in Ukraine, the destruction of conifers, and the emergence of small deciduous shrubs with undergrowth and tall grass, as well as severe cluttering of the landscape in some forest parks, the emergence of ro- 
dents and intensive construction in suburban areas. Therefore, the importance of preventive measures for Lyme borreliosis and toxoplasmosis in animals and humans, it is timely laboratory diagnosis and specific prevention.

Due to the above, it is necessary to create an operational algorithm for epidemiological surveillance of natural foci of infection transmitted by ticks (Fig. 2).

The algorithm involves the following actions:

- Epidemiological surveillance with Ixodes tick-borne borreliosis;

- Monitoring of objects or phenomena;

- Analysis of monitoring results;

- Decision making (development of a plan of preventive measures);

- Implementation of the action plan;

- Monitoring the effectiveness of measures;
- Correction of the monitoring program and the plan of preventive measures;

- If monitoring the effectiveness of measures showed positive results, then we suggest to repeat the epidemiological surveillance with Ixodes tick-borne borreliosis, according to the season favorable for the spread of ticks;

- If monitoring the effectiveness of measures showed a negative result, it is proposed to correct the monitoring program and the plan of preventive measures and repeating the algorithm cycle "Implementation of the action plan - Monitoring the effectiveness of measures".

The affiliation of Ixodes tick-borne borreliosis to natural focal infections determines the specifics of surveillance, which should be considered as epizooti-

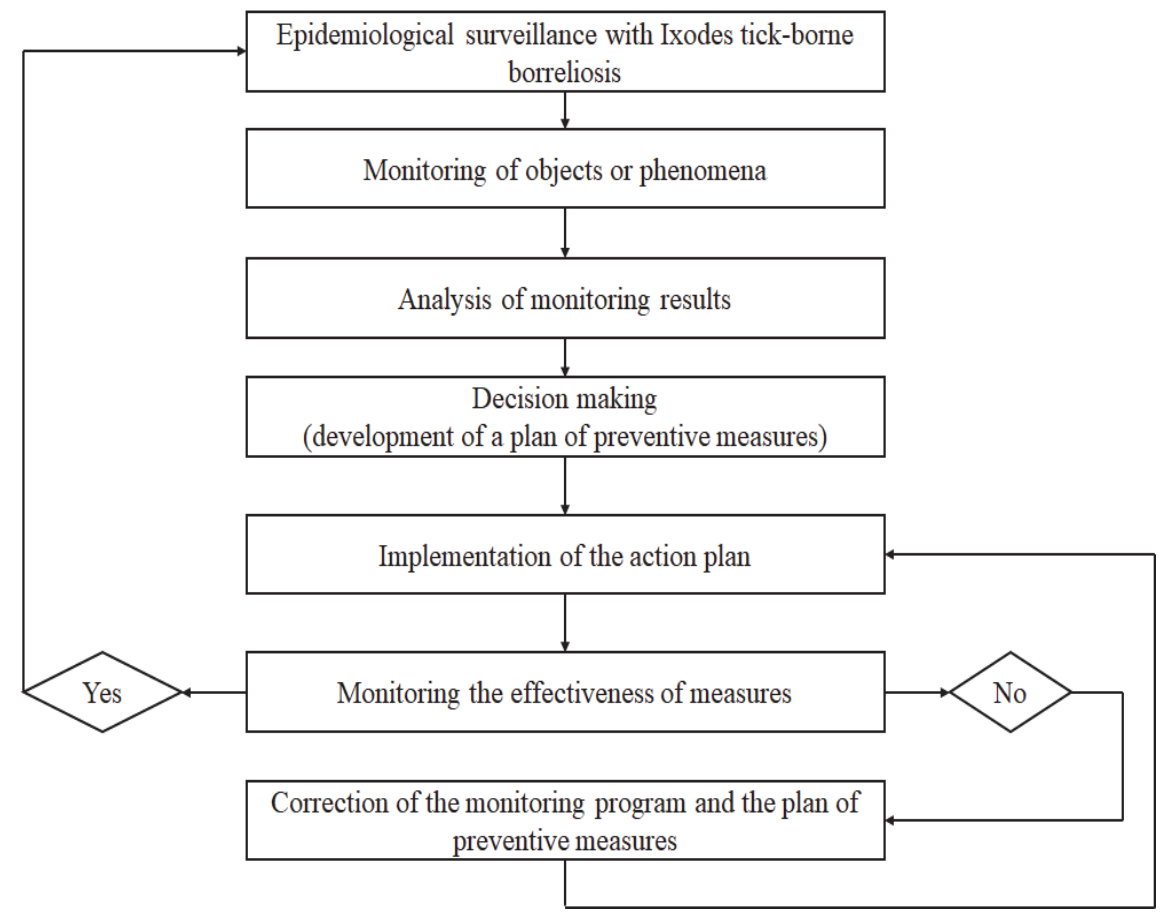

Fig 2. Algorithm for epidemiological surveillance of natural foci of tick-borne infections 
ological and epidemiological, including epidemiological, immunological, and zooentomological monitoring.

The epidemiological monitoring involves monitoring the intensity of the epidemic process, dynamics (perennial and seasonal), territorial distribution, and structure of the disease and includes laboratory examination of patients, an epidemiological examination of the case (or suspicion) of Ixodes tick-borne borreliosis. The distribution of morbidity around territory is traditionally grouped by administrative principles (cities and districts of the region, districts of the city).

The structure of the disease includes the distribution by sex, age, social and occupational composition with the selection of "risk groups", by clinical forms (1st stage - migratory erythema; 2nd-3rd stages - indicating the leading symptoms and severity of the course).

The epidemiological examination of the case (or suspicion) of Ixodes tickborne borrelios is a compulsory component of epidemiological monitoring. Sanitary and epidemiological station after receiving an emergency notification in case of disease or suspected Ixodes tick-borne borrelios (form N 058/o) conducts its epidemiological examination. Collection of information on epidemiological monitoring is carried out according to the data of official accounting documentation - the form N 357/o "Map of epidemiological inspection of the center of an infectious disease" (https://zakon.rada.gov.ua/laws/show/ z0115-16\#Text).

\section{Conclusions and future perspectives}

In the forest park areas of Kyiv and Kyiv region found Ixodes ticks and Dermacentor genera. Other genera of Ixodes ticks have not been registered.
The Laboratory tests revealed the presence of DNA of Borrelia burgdorferi and Toxoplasma gondii in adults, larvae, and nymphs of the genus Ixodes. In adults, larvae and nymphs of the genus Dermacentor these pathogens were not detected. The annual dynamics of infection with Borrelia burgdorferi and Toxoplasma gondii is characterized by a pronounced seasonality associated with the period of activity of ticks of the genus Ixodes. The highest number of Ixodes ticks attacks on dogs and humans is recorded in May-June and September-October. The presence of Borrelia burgdorferi in ticks of the genus Ixodes confirms the main natural source of infection with this pathogen in various species of animals and humans in Ukraine and, in particular, in Kyiv and the Kyiv region. At the same time, the detection of Toxoplasma gondii in Ixodes ticks indicates the presence of one of the possible sources of infection with the pathogen in animals and humans.

The research results show that a stable natural center of Lyme borreliosis and toxoplasmosis has formed in the forest park zones of Kyiv and Kyiv region.

To prevent the spread of infected ticks, in our opinion, it is important:

- timely prevention of animals from ticks;

- research of ticks in the territories of their possible spread;

- analysis of the ecological situation within three or four years in the area where ticks are most common;

- creation of maps with the help of Geographic Information Systems that reflect the dynamics of diseases transmitted by Ixodes mites; public awareness.

Prospects for further research are the search for effective acaricidal drugs, taking into account their toxicity. 


\section{References}

Afzelius, A. (1910). Verhandlungen der dermatologischen Gesellschaft zu Stockholm, December, 1909. Arch. Dermatol. Syphil. (Berlin), 101:405-406.

Appel, M. J., Allan, S. \& Jacobson, R. H. (1993). Experimental Lyme disease in dogs produced arthritis and persistent infection. Journal of Infectious Diseases, 167:651-664.

Burgdorfer, W. (1984). Discovery of the Lyme disease spirochete and its relation to tick vectors. Yale Journal of biology \& medicine, 57:518-520.

Galat, M. V. \& Boyko, O. B. (2016). Poshyrennia zbudnyka toksoplazmozu sered chlenystonohykh rodyny Ixodidae. [Spreading of toxoplasmosis agent among arthropods of the family Ixodidae] Scientific Bulletin of the National University of Life and Environmental Sciences of Ukraine, 237:365-372. (in Ukrainian).

Galat, V. F., Berezovsky A. V., Prus, M. P. \& Soroka, N. M. (2003). Parazytolohiia ta invaziini khvoroby tvaryn. Kyiv. Vyshcha osvita [Parasitology and invasive animal's diseases]. Kyiv: Vuscha ostia. (in Ukrainian).

Galatiuk, O. E., Peredera, O. O., Lavrinenko, I. V. \& Gernosik, I. A. (2018). Infektsiini khvoroby sobak [Infectious diseases of dogs]. Zhitomir: PP «Ruta». (in Ukrainian).

Gilbert, L., Aungier, J. \& Tomkins, J. L. (2014). Climate of origin affects tick (Ixodes ricinus) host-seeking behavior in response to temperature: implications for resilience to climate change? Ecology and evolution, 4(7):1186-1198.

Honig, V. (2015). Ticks and tick-borne pathogens in South Bohemia (Czech Republic) - Spatial variability in Ixodes ricinus abundance, Borrelia burgdorferi and tick-borne encephalitis virus prevalence. Ticks and Tick-borne Diseases, 6(5):559-567.

Honig, V. (2019). Model of Risk of Exposure to Lyme Borreliosis and Tick-Borne Encephalitis Virus-Infected Ticks in the Border Area of the Czech Republic (South Bohemia) and Germany (Lower Bavaria and Upper Palati- nate). International Journal of Environmental Research and Public Health, 16(7):1173. doi:10.3390/ijerph16071173

Klymniuk, S. I., Romaniuk, L. B., Kravets, N. Y., Tkachuk, N. I. \& Dronova, O. Y. (2017). Deiaki aspekty epidemiolohii ta diahnostyky Laim-boreliozu [Some aspects of the epidemiology and diagnosis of Lyme-borreliosis]. Scientific notes of Ternopil National Pedagogical University. Series: Biology, 3(70):147-152. (in Ukrainian).

Lindgren, E., Thomas, G. T. \& Lyme, J. (2006). Borreliosis in Europe: influences of climate and climate change, epidemiology, ecology and adaptation measures. Publications WHO Regional Office for Europe. 2006. Retrieved from http://www.euro.who.int/_data/assets/pdf_file/0006/96819/E89522.pdf

Lindenmayer, J. M., Marshall, D. \& Onderdonk, A. B. (1991). Dogs as sentinels for Lyme disease in Massachusets. American Journal of Public Health, 81(11):1448-1455.

Luginin, M. S. (2011). Ekolohichni osoblyvosti iksodovykh klishchiv (ixodidae) v bioheotsenozakh lisovykh nasadzhen Zaporizkoi oblasti [Ecological features of ixodic ticks (Ixodidae) in biogeocenoses of forest plantations of Zaporizhia region]. (Abstract of the dissertation thesis). Dnipropetrovsk, 21. (in Ukrainian).

Littman, M. P., Gerber, B., Goldstein, R. E., Labato, M. A., Lappin, M. R. \& Moore, G. E. (2018). ACVIM consensus update on Lyme borreliosis in dogs and cats. J. Vet. Intern. Med., 32(3):887-903.

Nikiforova, O. V. (2007). Vydovyi sklad, rozpovsiudzhennia i zakhody borotby z iksodovymy klishchamy (ixodidae) u Kharkivskii oblasti [Species composition, distribution and control measures against ixodic ticks (Ixodidae) in Kharkiv region]. (Abstract of the dissertation thesis). Kharkiv, 22. (in Ukrainian).

Randolph, S. E., Green, R. M., Hoodless, A. N. \& Peacey, M. F. (2002). An empirical quantitative framework for the seasonal population dynamics of the tick Ixodes ricinus. Int. J. Parasitol., 32:979-989. 
Regional Committee for Europe EUR/RC68/16 68th session Rome, Italy. September 2018. 17-20. WHO Regional Committee for Europe. Retrieved from http:// www.euro.who.int/__data/assets/pdf_ file/0010/378172/68wd16e_InvasiveMosquitoFramework_180522.pdf.

Steere, A. C., Malawista, S. E., Snydman, D. R., Shope, R. E., Andiman, W. A. \& Ross, M. R. (1977). Lyme arthritis: an epidemic of oligoarticular arthritis in children and adults in three connecticut communities. Arthritis Rheum., 20(1):7-17.

Švec, P. (2009). Využití GIS pro mapování klištat a klištaty přenášených patogenů v Jihočeském kraji. Geografie, 157-168.
Švec, P. (2019). The use of multi-criteria evaluation for the selection of study plots for monitoring of I. ricinus ticks - Example from Central Europe. Ticks and Tick-borne Diseases. 10(4):905910. doi: 10.1016/j.ttbdis.2019.04.014

Wilske, B., Fingerle, V. \& Schulte-Spechtel U. (2007). Microbiological and serological diagnosis of Lyme borreliosis. FEMS Immunol Med Microbiol., 49 (1):13-21.

Zubriková, D., Wittmann, M., Hönig, V. \& Švec, P. (2020). Prevalence of tick-borne encephalitis virus and Borrelia burgdorferi sensu lato in Ixodes ricinus ticks in Lower Bavaria and Upper Palatinate, Germany. Ticks and Tick-borne Diseases. doi: 10.1016/j.ttbdis.2020.101375

\section{Н. М. Сорока, В. В. Недосєков, Н. П. Овчарук, В. М. Овчарук, О. О. Кравчук} (2020). ІКСОДОВІ КЛІЩІ - ПЕРЕНОСНИКИ ЗБУДНИКІВ НЕБЕЗПЕЧНИХ ТРАНСМІСИВНИХ ІНФЕКЦІЙ ТА ІНВАЗІЙ. Ukrainian Journal of Veterinary Sciences, 11(3): 75-84, https://doi.org/10.31548/ujvs2020.03.008

Анотація. У статті розглядаються вітчизняний та зарубіжний досвід щодо поширення іксодових кліщів - переносників збудників небезпечних трансмісивних інфекцій та інвазій у лісопаркових зонах України і превентивних заходах щодо іксодідозів тварин та людини. Матеріалом для дослідження слугували дані ветеринарної звітності, отримані від державних регіональних лабораторій ветеринарної медицини за 2018-2019 роки. Дослідження проводилися на кафедрі паразитології та тропічної ветеринарії Національного університету біоресурсів і природокористування України. Для досліджень використовували іксодових кліщів, попередньо зібраних у лісопаркових зонах Києва. Аналізувалися результати дослідження іксодових кліщів на наявність збудників небезпечних трансмісивних інфекцій та інвазій, а також лікування собак за іксодідозів.

Для запобігання поширенню інфікованих клішів важливими нами визначено своєчасна профрілактика тварин від кліщів, дослідження кліщів на територіях їхнього можливого розповсюдження; аналіз екологічної ситуації в межах трьох-чотирьох років на території, де найчастіше розповсюджуються кліші; створення мап за допомогою Географрічних інформаційних систем, що відображають динаміку хвороб, що передаються іксодовими кліщами; інформування населення.

Перспективами подальших наукових досліджень $\epsilon$ пошук ефективних акарицидних препаратів із врахуванням їхньої токсичності.

Ключові слова: іксодові кліщі, поширення, ризики, трансмісивні хвороби, іксодідози тварин 